\title{
Isolasi dan identifikasi bakteri aerob yang berpotensi menjadi sumber penularan infeksi nosokomial di ruang ICU Rsad Robert Wolter Mongisidi Teling Manado
}

\author{
${ }^{1}$ Hilary G. Sarlin \\ ${ }^{2}$ Heriyannis Homenta \\ ${ }^{2}$ John Porotu'o
}

\author{
${ }^{1}$ Kandidat Skripsi Fakultas Kedokteran Universitas Sam Ratulangi Manado \\ ${ }^{2}$ Bagian Mikrobiologi Fakultas Kedokteran Universitas Sam Ratulangi Manado \\ Email: Hilygs@gmail.com
}

\begin{abstract}
Nosocomial infections are infections that arise during the patient was hospitalized and starting to show symptoms for a person being treated or after completion of treatment. Patients in the ICU may have a tendency to nosocomial infections. The purpose of the study is to identify and knowing the most common aerobic bacteria that cause nosocomial infections in the ICU RSAD Robert Wolter Monginsidi Teling Manado.This research is a descriptive cross sectional study. The study samplesare bacteria on the floor, walls, air, bed, and ECG in the ICU RSAD Teling Robert Wolter Monginsidi Manado. The results showed 26 samples out of 26 samples contained bacteria, Bacillus sp. eight samples (30.7\%), Enterobacter aerogens six samples (23\%), Staphylococcus sp. six samples (23\%) and Enterobacter cloacae, Serratia liquefaciens, Serratia rubidaea, Serratia marcescens, Klebsiella pneumoniae, Proteus sp. each found as many as one sample (3.8\%). Conclusion: The most common bacteria is Bacillus sp.
\end{abstract}

Keywords: nosocomial infection, ICU, aerobic bacteria

\begin{abstract}
Abstrak: Infeksi nosokomial adalah Infeksi yang muncul selama penderita tersebut dirawat dirumah sakit dan mulai menunjukkan suatu gejala selama seseorang itu dirawat atau setelah selesai dirawat. Pasien yang berada di ruang ICU dapat mempunyai kecenderungan terkena infeksi nosokomial. Penelitian ini bertujuan untuk mengidentifikasi dan mengetahui bakteri aerob yang terbanyak penyebab infeksi nosokomial di ruang ICU RSAD Robert Wolter Mongisidi Teling Manado. Desain penelitian ini bersifat deskriptif dengan studi cross sectional. Sampel penelitian ialah bakteri pada lantai, dinding, udara, tempat tidur, dan EKG di ruang ICU RSAD Robert Wolter Mongisidi Teling Manado. Hasil penelitian memperlihatkan dari 26 sampel terdapat 26 sampel yang tumbuh yaitu, Bacillus sp. sebanyak delapan sampel (30,7\%), Enterobacter aerogens ditemukan sebanyak enam sampel (23\%), Staphylococcus sp. Ditemukan sebanyak enam sampel (23\%) sedangkan Enterobacter cloacae, Serratia liquefaciens, Serratia rubidaea, Serratia marcescens, Klebsiella pneumoniae, Proteus sp. masing-masing ditemukan sebanyak satu sampel (3,8\%). Simpulan: bakteri yang paling banyak ditemukan adalah Bacillus sp.
\end{abstract}

Kata kunci: infeksi nosokomial, ICU, bakteri aerob

Penyakit infeksi adalah penyakit yang disebabkan oleh mikroba pathogen dan bersifat dinamis. Di negara berkembang masih merupakan penyebab utama tingginya angka kesakitan (morbidity) dan angka kematian (mortality) di rumah sakit, dimana infeksi ini lebih di kenal dengan istilah infeksi nosokomial. ${ }^{1}$ Istilah nosokomial berasal dari bahasa Yunani yang berarti nosokomeion yang berarti 
rumah sakit $($ nosos $=$ penyakit, dan komeo $=$ merawat) infeksi nosokomial dapat diartikan infeksi yang berasal atau terjadi di rumah sakit. ${ }^{2,3,4}$ Infeksi yang muncul selama penderita tersebut dirawat dirumah sakit dan mulai menunjukkan suatu gejala selama seseorang itu dirawat atau setelah selesai dirawat disebut infeksi nosokomial. ${ }^{5}$ Infeksi nosokomial dapat terjadi pada penderita, tenaga kesehatan, dan juga setiap orang yang datang ke rumah sakit. Manifestasi penyakit dapat terjadi di rumah sakit, tetapi dapat juga di luar rumah sakit apabila inkubasi lebih lama dari masa tinggalnya di rumah sakit. Sumber kuman infeksi nosokomial dapat endogen atau autogen, yaitu berasal dari penderita sendiri yang dibawa dari rumah sakit, atau eksogen yang berasal dari luar penderita. ${ }^{6}$

Penelitian yang dilakukan londok,dkk di ruang ICU BLU RSUP Prof. dr. R.D Kandou Manado tahun 2015 ,dari 27 sampel yang diperiksa, 24 sampel terjadi pertumbuhan dan pada uji biokimia ditemukan bakteri Enterobacter aggloemerans sebanyak enam sampel (25\%), Bacillus subtilis lima sampel (20,8\%), Enterobacter cloacae 4 sampel (16,8\%), kokus Gram negatif empat sampel (16,8\%), Staphylococcus sp. 2 sampel $(8,3 \%)$, Serratia rubidaea satu sampel $(4,1 \%){ }^{7} \quad$ Selain itu Penelitian yang dilakukan National Nosokomial Infections Surveillance (NNIS) dan Centers of Disease Control and prevention's (CDC's) pada tahun 2002 melaporkan bahwa 5 sampai 6 kasus infeksi nosokomial dari setiap 100 kunjungan ke rumah sakit. Diperkirakan 2 juta kasus infeksi nosokomial terjadi setiap tahun di Amerika Serikat. ${ }^{8}$ Penelitian diberbagai universitas di Amerika Serikat menyebutkan bahwa pasien yang dirawat di Intensive Care Unit (ICU) mempunyai kecenderungan terkena infeksi nosokomial 5-8 kali lebih tinggi dari pada pasien yang dirawat di ruang rawat biasa. Infeksi Nosokomial banyak terjadi di ICU pada kasus pasca bedah dan kasus pemasangan infus dan kateter yang tidak sesuai prosedur standar pencegahan dan pengendalian infeksi yang diterapkan di rumah sakit. ${ }^{9}$

Berdasarkan latar belakang di atas dan mengingat pentingnya pengawasan terhadap kesehatan di ruang ICU dan pada pasien pasca bedah terhadap infeksi nosokomial, maka peneliti tertarik untuk melakukan penelitian tentang Isolasi dan Identifikasi Bakteri Aerob yang Berpotensi Menjadi Sumber Infeksi Nosokomial di Ruang ICU RSAD Robert Wolter Mongisidi Teling Manado.

\section{METODE PENELITIAN}

Penelitian ini menggunakan metode penelitian deskriptif cross sectional dengan menggunakan pendekatan prospektif. Penelitian ini dilaksanakan pada Agustus sampai November 2016. Terdapat 26 sampel dalam penelitian ini yang berasal dari dinding, lantai,perabotan ruangan, peralatan medis dan udara di ruang ICU (Intensive Care Unit) RSAD Robert Wolter Mongisidi Manado. Pengelolaan sampel dilakukan di Laboratorium Mikrobiologi Fakultas Kedokteran Universitas Sam Ratulangi Manado dengan pewarnaan Gram dan dilanjutkan dengan uji biokimia.

\section{HASIL PENELITIAN}

Berdasarkan penelitian yang dilakukan selama bulan Agustus-November 2016 telah dilakukan pengambilan sampel di ruang ICU RSAD Robert Wolter Mongisidi Manado.

Pada Tabel 1 pengambilan sampel dilakukan di ruangan gawat darurat medik terdiri dari 26 sampel yaitu 5 sampel dari lantai 4 sampel dari dinding, 1 sampel dari tempat tidur, 1 sampel dari alat EKG, dan 15 udara yaitu: 5 udara pagi, 5 udara siang dan 5 udara sore.

Pada Tabel 2 dapat dilihat pertumbuhan bakteri pada Nutrient Agar sebanyak 24 sampel, Mac Conkey Agar sebanyak 15 sampel, dan Agar darah sebanyak 23 sampel, sedangkan yang tidak ada pertumbuhan bakteri terdapat pada Nutrient Agar sebanyak 2 sampel, Mac Conkey Agar sebanyak 11 sampel dan agar Darah sebanyak 3 sampel. 
Tabel 1. Distribusi Pengambilan Sampel

\begin{tabular}{ccc}
\hline Kategori & Sampel & $\begin{array}{c}\text { Jumlah } \\
\text { Sampel }\end{array}$ \\
\hline Ruang ICU & Lantai & 5 \\
Dinding & 4 \\
Perabotan & Tempat & 1 \\
Ruangan & tidur & \\
Peralatan & EKG & 1 \\
Medis & & \\
Udara & Pagi & 1 \\
& Siang & 1 \\
& Sore & 1 \\
Total & & $\mathbf{2 6}$ \\
\hline
\end{tabular}

Tabel 2. Distribusi Pertumbuhan Bakteri

\begin{tabular}{ccc}
\hline Media Isolasi & \multicolumn{2}{c}{ Hasil Pertumbuhan } \\
& AP & TAP \\
\hline Nutrient Agar & 24 & 2 \\
Mac Conkey & 15 & 11 \\
Agar & & 3 \\
Agar Darah & 23 & $\mathbf{1 6}$ \\
Total & $\mathbf{6 2}$ & \\
\hline
\end{tabular}

Pada Tabel 3 dapat dilihat Bakteri yang terbanyak pada pewarnaan Gram yaitu bakteri Gram positif.

Tabel 3. Hasil Pewarnaan Gram

\begin{tabular}{cccc}
\hline $\begin{array}{c}\text { Pewarnaan } \\
\text { Gram }\end{array}$ & $\begin{array}{c}\text { Nutrien } \\
\text { Agar }\end{array}$ & $\begin{array}{c}\text { Mac } \\
\text { Conkey } \\
\text { Agar }\end{array}$ & $\begin{array}{c}\text { Agar } \\
\text { Darah }\end{array}$ \\
\hline Gram & 17 & - & 25 \\
$\begin{array}{c}\text { Positif } \\
\text { Gram }\end{array}$ & 9 & 9 & - \\
$\begin{array}{c}\text { Negatif } \\
\text { Total }\end{array}$ & $\mathbf{2 6}$ & $\mathbf{9}$ & $\mathbf{2 5}$ \\
\hline
\end{tabular}

Pada Tabel 4 menunjukan bakteri yang didapat berjumlah 26 bakteri, terdiri dari Bacillus sp. sebanyak 8 sampel (30,7\%), Enterobacter aerogens ditemukan sebanyak enam sampel (23\%), Staphylococcus sp. ditemukan sebanyak enam sampel (23\%) sedangkan Enterobacter cloacae, Serratia liquefaciens, Serratia rubidaea, Serratia marcescens, Klebsiella pneumoniae dan Proteus sp. masing-masing ditemukan sebanyak satu sampel $(3,8 \%)$
Tabel 4. Hasil Distribusi Bakteri

\begin{tabular}{ccc}
\hline Bakteri & Jumlah & $(\%)$ \\
\hline $\begin{array}{c}\text { Bacillus sp. } \\
\text { Enterobacter } \\
\text { aerogens }\end{array}$ & 8 & $30,7 \%$ \\
$\begin{array}{c}\text { Staphylococcus } \\
\text { sp. }\end{array}$ & 6 & $23 \%$ \\
$\begin{array}{c}\text { Serratia } \\
\text { liquefaciens }\end{array}$ & 1 & $23 \%$ \\
$\begin{array}{c}\text { Serratia } \\
\text { marcescens }\end{array}$ & 1 & $3,8 \%$ \\
Serratia rubidaea & 1 & $3,8 \%$ \\
Klebsiella & 1 & $3,8 \%$ \\
pneumoniae & 1 & $3,8 \%$ \\
Enterobacter & & \\
cloacae & 1 & $3,8 \%$ \\
Proteus sp. & 1 & $\mathbf{1 0 0}$ \\
$\quad$ Total & $\mathbf{6 0}$ & \\
\hline
\end{tabular}

Tabel 5 menunjukkan pertumbuhan 3 jenis bakteri pada dinding yaitu Bacillus sp. sebanyak 1 sampel (25\%), Enterobacter aerogens sebanyak 2 sampel (50\%) dan Serratia liquefaciens (25\%).

Tabel 5. Bakteri pada Sampel Dinding

\begin{tabular}{ccc}
\hline Bakteri & Jumlah & $\mathbf{( \% )}$ \\
\hline Bacillus $s p$. & 1 & $25 \%$ \\
Enterobacter & 2 & $50 \%$ \\
aerogens & & \\
$\begin{array}{c}\text { Serratia } \\
\text { liquefaciens } \\
\text { Total }\end{array}$ & 1 & $25 \%$ \\
\hline
\end{tabular}

Tabel 6 menunjukkan pertumbuhan 3 jenis bakteri pada lantai yaitu Bacillus sp. sebanyak 2 sampel (40\%), Staphylococcus $s p$. sebanyak 2 sampel (40\%), dan sampel Proteus sp. sebanyak 1 sampel (20\%).

Tabel 6. Bakteri di Lantai

\begin{tabular}{ccc}
\hline Bakteri & Jumlah & $(\boldsymbol{\%})$ \\
\hline Bacillus $s p$. & 2 & $40 \%$ \\
Staphylococcus & 2 & $40 \%$ \\
sp. & 1 & $20 \%$ \\
Proteus $s p$. & $\mathbf{1 1}$ & $\mathbf{1 0 0}$ \\
Total &
\end{tabular}


Tabel 7 menunjukkan bakteri yang terdapat pada tempat tidur yaitu Staphylococcus sp. sebanyak 1 sampel (100\%).

Tabel 7. Bakteri di Perabotan Ruangan

\begin{tabular}{ccc}
\hline Bakteri & Jumlah & $\mathbf{( \% )}$ \\
\hline $\begin{array}{c}\text { Staphylococcus } \\
\text { sp. } \\
\text { Total }\end{array}$ & 1 & $100 \%$ \\
\hline
\end{tabular}

Tabel 8 menunjukkan bakteri yang terdapat pada peralatan medis (EKG) ditemukan bakteri Serratia rubidaea sebanyak satu sampel (100\%).

Tabel 8. Bakteri di Peralatan Medis

\begin{tabular}{lcc}
\hline Bakteri & Jumlah & $\mathbf{( \% )}$ \\
\hline $\begin{array}{l}\text { Serratia } \\
\text { rubidaea }\end{array}$ & 1 & $100 \%$ \\
Total & $\mathbf{1}$ & $\mathbf{1 0 0}$ \\
\hline
\end{tabular}

Tabel 9 menunjukkan terdapat 5 bakteri yaitu, Staphylococcus sp., Serratia marcescens, Enterobacter aerogens, Bacillus sp., Klebsiella pneumoniae, masing-masing satu sampel (20\%).

Tabel 9. Bakteri di Udara Pagi

\begin{tabular}{ccc}
\hline Bakteri & Jumlah & $(\mathbf{\%})$ \\
\hline $\begin{array}{c}\text { Staphylococcus } \\
\text { sp. }\end{array}$ & 1 & $20 \%$ \\
$\begin{array}{c}\text { Serratia } \\
\text { marcescens }\end{array}$ & 1 & $20 \%$ \\
Enterobacter & & \\
aerogens & 1 & $20 \%$ \\
Bacillus sp. & 1 & $20 \%$ \\
Klebsiella & 1 & $20 \%$ \\
pneumoniae. & 1 & $\mathbf{1 0 0}$ \\
Total & $\mathbf{1 0}$ &
\end{tabular}

Tabel 10 menunjukkan terdapat 3 bakteri yaitu, Bacillus sp., sebanyak tiga sampel (60\%), Staphylococcus sp. sebanyak satu sampel (20\%), Enterobacter aerogens sebanyak satu sampel (20\%).

Tabel 11 menunjukkan terdapat 4 bakteri yang ditemukan pada sampel udara sore yaitu, Enterobacter aerogens sebanyak dua sampel (40\%), Bacillus sp., Enterobacter cloacae, Staphylococcus sp. masing-masing sebanyak satu sampel $(20 \%)$.

Tabel 10. Bakteri Udara Siang

\begin{tabular}{ccc}
\hline Bakteri & Jumlah & $\mathbf{( \% )}$ \\
\hline Staphylococcus sp. & 1 & $20 \%$ \\
Bacillus sp. & 3 & $60 \%$ \\
Enterobacter & 1 & $20 \%$ \\
aerogens & & $\mathbf{1 0 0}$ \\
\hline Total & $\mathbf{1 0}$ & \\
\hline
\end{tabular}

Tabel 11. Bakteri Udara Sore

\begin{tabular}{ccc}
\hline Bakteri & Jumlah & $\mathbf{( \% )}$ \\
\hline Enterobacter & 2 & $40 \%$ \\
aerogens & 1 & $20 \%$ \\
Bacillus $s p$. & 1 & $20 \%$ \\
Enterobacter & 1 & \\
cloacae & & $20 \%$ \\
Staphylococcus & 1 & $\mathbf{1 0 0}$ \\
sp. & $\mathbf{1 5}$ & \\
Total & &
\end{tabular}

\section{BAHASAN}

Dalam periode Agustus - November 2016, telah dilakukan pengambilan sampel dan telah di teliti berupa usapan di ruang perawatan seperti lantai dan dinding, perabotan ruangan seperti tempat tidur, peralatan medis seperti EKG, dan udara pagi, siang dan sore di ruang ICU RSAD Robert Wolter Mongisidi Teling Manado sebanyak 26 sampel dan dilakukan pemeriksaan di Laboratorium Mikrobiologi Fakultas Kedokteran Universitas Sam Ratulangi Manado.

Berdasarkan hasil yang telah didapatkan, terdapat 26 sampel dan ditemukan beberpa jenis bakteri yang berpotensi menyebabkan infeksi nosokomial. Pada hasil identifikasi bakteri ditemukan tujuh spesies bakteri yang berpotensi menyebabkan infeksi nosokomial yaitu, Bacillus sp. sebanyak delapan sampel $(30,7 \% \%)$, Enterobacter aerogens ditemukan sebanyak enam sampel (23\%), Staphylococcus sp. ditemukan sebanyak enam sampel $(23 \%)$ sedangkan Enterobacter cloacae, Serratia 
liquefaciens, Serratia rubidaea, Serratia marcescens, Proteus sp., Klebsiella pneumoniae masing-masing ditemukan sebanyak satu sampel $(3,8 \%)$.

Bakteri Bacillus sp. adalah bakteri gram positif. Pada penelitian ini Bacillus $s p$. adalah bakteri yang paling banyak ditemukan pada penelitian ini yaitu sebanyak delapan sampel $(30,7 \%)$, dan sebagian besarnya terdapat pada sampel udara. Hal ini kemungkinan disebabkan karena pintu yang sering dibuka sehingga memudahkan kontaminasi dari luar atau penyebab lain berasal dari AC (air conditioning) yang kotor. Hasil penelitian ini sama dengan yang didapatkan pada kultur bakteri udara ruang ICU RSUP dr. Wahidin Sudirohusodo Makassar tahun 2011 yang menemukan bakteri Bacillus sp. sebanyak $(10 \%) .^{10}$

Enterobacter aerogens adalah bakteri patogen karena dapat menyebabkan berbagai jenis infeksi. Pada penelitian ini, infeksi dapat terjadi melalui udara karena ditemukan enam sampel (23\%) yang sebagian besar sampel tersebut berasal dari sampel udara ruangan, hal ini terjadi kemungkinan karena kebersihan udara ruangan yang jarang dibersihkan, atau dapat juga berasal dari petugas kesehatan karena menurut hasil penelitian Zahriyah di Ruang ICU Pusat Jantung Nasional Harapan Kita Jakarta tahun 2004 menyebutkan bahwa bakteri yang banyak terdapat pada tangan perawat adalah Enterobacter aerogens. ${ }^{11}$

Staphylococcus sp. sering ditemukan sebagai flora normal yang dapat ditemukan pada kulit dan selaput lendir pada manusia. Pada penelitian ini telah ditemukan bakteri Staphylococcus sp. sebanyak enam sampel (23\%) yang terdapat di lantai, tempat tidur, udara pagi, udara siang, dan udara sore. Bakteri yang ditemukan pada penelitian ini, dapat mengakibatkan timbulnya infeksi nosokomial, misalnya pada pasien yang mengalami ulkus dekubitus karena tirah baring lama, ulkus dekubitus dapat menyebabkan bakteremia dan dapat menimbulkan komplikasi misalnya sepsis dan kematian, hal ini disebabkan terdapat bakteri Staphylococcus sp. di tempat tidur karena kemungkinan tempat tidur yang jarang disterilkan/didesinfeksikan. Hal ini didukung dengan pernyataan dari Lukmanul Hakim Nasution dari hasil penelitiannya yang menyatakan bahwa bakteri yang paling sering diisolasi dari pasien ulkus dekubitus adalah Staphylococcus aureus. ${ }^{12}$

Bakteri Enterobacter cloacae merupakan batang Gram-negatif sering ditemukan pada unit perawatan intensif (ICU). Pada hasil penelitian ini ditemukan bakteri Enterobacter cloacae sebanyak satu sampel $(3,8 \%)$ yang terdapat pada udara sore. Bakteri ini dapat menyebabkan infeksi pada saluran nafas karena ditemukan satu sampel bakteri di udara sore. Hal ini kemungkinan disebabkan karena kurang diperhatikannya kebersihan di ruang ICU. Hal yang sama ditemukan oleh Londok,dkk tahun 2015 di Ruang ICU (Intensive Care Unit) RSUP Prof. Dr. R. D Kandou Manado menemukan bakteri Enterobacter cloacae di sampel udara sebanyak 2 sampel (33\%). ${ }^{13}$

Serratia liquefaciens merupakan bakteri gram negatif yang tersebar luas di lingkungan, tanah, air dan tanaman. Pada penelitian ini ditemukan bakteri Serratia liquefaciens sebanyak satu sampel $(3,8 \%)$ yang berasal dari sampel dinding. Penyebab bakteri ini ditemukan kemungkinan disebabkan karena kontaminasi yang berasal dari luar misalnya dari pengunjung atau petugas di ruang ICU misalnya tangan yang kurang hygine. Bakteri Serratia liquefaciens dapat menyebabkan infeksi pada pasien seperti bakterimia, pneumoni, dan gastroenteritis. ${ }^{14}$

Serratia rubidaea merupakan bakteri yang termasuk dalam family Enterobacteriaceae. ${ }^{15}$ Pada penelitian ini ditemukan bakteri Serratia rubidaea sebanyak satu sampel $(3,8 \%)$ yang di dapatkan dari sampel peralatan medis (EKG). Kemungkinan terkontaminasinya EKG dengan bakteri ini disebabkan karena EKG yang diletakan di meja yang tidak steril atau kotor. Hal ini berkaitan dengan bakteri Serratia rubidaea yang ditemukan 
di EKG yang dapat menginfeksi pasien pasca operasi bedah yang menggunakan EKG.

Pada penelitian ini ditemukan bakteri Serratia marcescens pada udara pagi sebanyak 1 sampel (3,8\%). Hasil yang ditemukan pada penelitian ini sama dengan penelitian yang dilakukan oleh Khana,dkk yang menemukan Serratia marcescens di ICU. ${ }^{16}$

Klebsiella pneumoniae merupakan bakteri patogen, yang merupakan salah satu penyebab infeksi nosokomial, infeksi sering bersifat oportunis dan terjadi pada pasien rawat inap terutama di ICU. Klebsiella pneumoniae terdapat dalam saluran nafas dan feses pada sekitar 5\% orang normal. Operasi yang melibatkan saluran usus dan saluran kemih berpeluang untuk terjadinya kontaminasi Klebsiella sp. yang menyebabkan infeksi pada luka post operasi. Pada penelitian ini Klebsiella pneumoniae ditemukan sebanyak satu sampel $(3,8 \%)$ di sampel udara pagi. hasil penelitian ini sama yang dilakukan oleh Naldu ,dkk yang menemukan Klebsiella pneumonia di ruang ICU. ${ }^{17,18}$

Proteus sp. termasuk dalam family Enterobacteriacae. Proteus sp. merupakan penyebab infeksi saluran kemih, abses, dan infeksi luka bahkan dapat menyebabkan diare pada anak-anak. pada penelitian ini ditemukan Proteus sp. sebanyak satu sampel $(3,8 \%)$ dari sampel lantai. Hal ini kemungkinan disebabkan lantai yang jarang di sapu atau dipel sehingga ditemukan bakteri ini atau dapat juga berasal dari air yang terkontaminasi Proteus sp. ${ }^{19}$

Berdasarkan dari penelitian yang telah dilakukan bahwa telah ditemukan beberapa macam bakteri di ruang ICU RSAD Wolter Mongisidi Teling Manado. Ditemukannya bakteri ini, kemungkinan besar disebabkan oleh beberapa hal seperti ruangan yang lembab, perilaku tidak mencuci tangan, tidak memakai masker dan sarung tangan dan ruangan yang tidak dibersihkan dengan benar oleh petugas kebersihan. Pengendalian infeksi nosokomial harus dilakukan secara teratur. Program pengendalian tersebut dapat efektif jika semuanya bertindak secara komprehensif dan adanya pelatihan staf rumah sakit.

\section{SIMPULAN}

Berdasarkan hasil penelitian pola bakteri aerob yang berpotensi menyebabkan infeksi nosokomial diruang ICU RSAD Robert Wolter Mongisidi Teling Manado didapatkan Bacilus sp. (30,7\%), Enterobacter aerogens (23\%), Staphylococcus sp. (23\%) serta Enterobacter cloacae, Serratia liquefaciens, Serratia rubidaea, Serratia marcescens, dan Klebsiella pneumoniae, Proteus sp. (masing-masing 3,8\%). Dapat disimpulkan bahwa bakteri terbanyak ialah bakteri Bacillus sp.

\section{SARAN}

1. Pemeriksaan mikrobiologi lingkungan di rumah sakit harus dilakukan secara rutin yaitu setiap 6 bulan sekali

2. Peralatan medis yang digunakan harus disterilkan dengan baik sesuai standar dan peralatan medis harus disimpan dengan baik agar dapat menghindari kontaminasi

3. Petugas kesehatan harus melakukan teknik cuci tangan yang benar sebelum dan sesudah kontak dengan pasien

\section{DAFTAR PUSTAKA}

1. Nadia R. Profil Kultur dan Uji Sensitivitas bakteri Aerob dan infeksi Luka Operasi Laparatomi di Bangsal bedah RSUP DR. M Djamil Padan (online). 2011

2. Darmadi. 2008. Infeksi Nosokomial Problematika dan Pengendaliannya. Salemba Medika. Jakarta

3. Epidemiology of nosocomial infections. Dalam: Ducel G, Fabry J,Niccole L,penyunting. Prevention of hospital acquaired infection a practical guide. Edisi ke- 2. malta: World Health Organization; 2002. H.4-8 [disitasi 7 september 2016]

4. Bhatia A. Nosocomial Infections and IV infusion systems.2004. \{disitasi 9 september 2016 ] tersedia dari :www.expresshealthcaremgmt.com/2 
0040915/management02.shtml.

5. Salawati L. Pengendalian Infeksi Nosokomial.2012;1

6. Satyaputra DW. Pengendalian infeksi nosokomial di RSU Bekasi. Cermin dunia kedokteran 1993;82;18-20

7. Londok P, Homenta H, Buntuan V. Pola bakteri aerob yang berpotensi menyebabkan infeksi nosokomial di ruang ICU BLU RSUP Prof.DR.R.D. Kandou Manado. Jurnal E-Biomedik (EBM)2015;1:1

8. Broaddus E, Fu R. Hospital-acquired infections. [disitasi 8 september 2016].

9. PMK No. 12 Tahun 2013 Tentang Pola Tarif Badan Layanan Umum di lingkungan Kementrian Kesehatan

10.Noer S.F. Pola Bakteri dan Resistensinya terhadap Antibiotik yang ditemukan pada Air dan Udara Ruang Instalasi Rawat Khusus RSUP Dr. Wahidin Sudirohusodo Makassar. Universitas Islam Makassar. 2011

11.Angga L,dkk. Identifikasi jenis bakteri kontaminan pada tangan perawat dibangsal penyakit dalam RSUD Ulin Banjarmasin periode Juni-Agustus 2014.2015;11:14

12.LH Nasution. 2012. Infeksi Nosokomial. Departemen Ilmu Kesehatan Kulit dan Kelamin. 2012;39:39

13.Londok P, Homenta H, Buntuan V. Pola
Bakteri Aerob yang Berpotensi Menyebabkan Infeksi Nosokomial di Ruang ICU BLU RSUP DR. R. D. Kandou Manado. Jurnal E-Biomedik (EBM)2015;3

14. MicrobeWiki.Serratia liquefaciens. 2012 May $10 \quad$ [cited 2016 Nop 16].Available from https://microbewiki.kenyon.edu/index .php/Serratia_liquefaciens

15.Grimont F, Grimont $P$. The genus Serratia. 2012;6:219

16.Khanna A, Khanna M, Aruna A.Serratia Marcescens A Rare Opportunistic Nosocomial Pathogen and Measures to Limit its Spread in Hospitalized Patients.2012;7

17.Naldu, et al. A descriptive study of nosocomial infections in an adult intensive care unit in Fiji.2011

18. Warganegara E, Apriliana E, Ardiansyah R. Identifikasi bakteri penyebab luka operasi (ILO) nosokomial pada ruang rawat inap bedah dan kebidanan RSAM di bandar lampung.2012;3:347

19.Digilib Unimus. Bakteri proteus $s p$. 2012[cited 2016 nop 18]. Available from

digilib.unimus.ac.id/download.php?id $=2952$ 